\title{
Quantitative Evaluation of the Weak Acid Hypothesis as the Mechanism for 2,4-D Absorption by Corn Root Protoplasts*
}

\author{
Fumito KASAI** and David E. BAYER \\ Department of Botany, University of California, Davis, California 95616, U.S.A.
}

(Received July 20, 1990)

\begin{abstract}
The absorption of 2,4-D by protoplasts enzymatically isolated from the cortex of corn (Zea mays L. cv Pioneer 3377) root was investigated in relation to their extracellular and intracellular $\mathrm{pH}$. The 2,4-D absorption increased as the extracellular $\mathrm{pH}\left(\mathrm{pH}^{\circ}\right)$ decreased. The ratio of the 2,4-D concentration inside to outside the protoplasts $\left(c^{\mathrm{i}} / c^{\circ}\right)$ reached $c a$. 1.2, $4.0,10-12$ and $30-40$ at $\mathrm{pH}^{\circ} 7.5,6.5,5.5$ and 4.5 respectively, within 75 min incubation. At $\mathrm{pH}^{\circ} 3.5$ and $2.8, c^{\mathrm{i}} / c^{\circ}$ ratio reached $c a .90$ and 150 respectively within $15 \mathrm{~min}$, but the absorbed 2,4-D was rapidly released after $15 \mathrm{~min}$ incubation due to the death of the protoplasts. The determination of the overall intracellular $\mathrm{pH}\left(\mathrm{pH}^{\mathrm{i}}\right)$ by the 5,5-dimethyloxazolidine-2,4-dione distribution technique indicated that the change of the $\mathrm{pH}^{\mathrm{i}}$ as influenced by the $\mathrm{pH}^{\circ}$ variation (7.5 to 4.5 ) was relatively small (6.9 to 6.6). Using the measured $\mathrm{pH}^{\mathrm{i}}$, the theoretical $c^{\mathrm{i}} / c^{\circ}$ ratio at each $\mathrm{pH}^{\circ}$ was estimated based on the weak acid hypothesis. Although the $\mathrm{pH}^{\circ}$ dependence of the theoretical $c^{\mathrm{i}} / c^{\circ}$ roughly resembled the observed tendency, the measured $c^{\mathrm{i}} / c^{\circ}$ ratios at $\mathrm{pH}^{\circ} 6.5$ and 7.5 were significantly greater than their respective theoretical maxima. These results suggest that the absorption of 2,4-D by protoplasts cannot be accounted for simply by the weak acid hypothesis and that an active transport is involved at least at $\mathrm{pH}^{\circ} 6.5$ and 7.5 .
\end{abstract}

\section{INTRODUCTION}

It has been well established that a phenoxy herbicide, 2,4-D, has a "symplastic" property in terms of absorption and translocation in plant systems. ${ }^{1-3)}$ Several lines of experimental evidence have indicated that 2,4-D is capable of being effectively absorbed into cytoplasm and retained in the symplast. ${ }^{1-5)}$ If the mechanism for such symplastic mobility of 2,4-D could be exactly described, the results would provide important clues to elucidate plant transport systems as well as to help design chemical structures for new symplastic her-

* Influence of Intracellular pH on Absorption of 2,4-D by Corn Root Protoplasts (Part 1).

** Present address: Agrochemicals Development and Technical Services Department, Sankyo Co., Ltd., 2-chome, Ginza, Tokyo 104, Japan. bicides or phytohormones. Unfortunately, the exact mechanism of 2,4-D absorption is still unclear in spite of extensive investigations carried out.

The weak acid hypothesis (or the ion trap theory) has been used to explain the symplastic mobility of weak acid xenobiotics including 2,4-D. ${ }^{3,4,6,7)}$ The hypothesis is briefed as follows: The transport of weak acids across plasmalemma occurs mainly by passive diffusion of the undissociated molecules due to their lipophilicity. Once inside the symplast (the cytoplasm or the sieve tube), the molecules dissociate into anions due to the higher $\mathrm{pH}$ of the symplast. The hydrophilic anions are unable to diffuse back through the plasmalemma causing the anions to accumulate within the symplast.

There have been, however, two major 
difficulties in quantitatively evaluating the validity of this hypothesis. First, the presence of the cell wall or free space in plant systems makes it difficult to accurately determine the intracellular solute concentration. Even the extracellular conditions to which the plasmalemma is directly exposed may be different from the bathing buffer if the cell wall is covering the plasmalemma. Second, the intracellular $\mathrm{pH}\left(\mathrm{pH}^{\mathrm{i}}\right)$ of plant cells must be determined during the absorption process. In fact, although the $\mathrm{pH}^{\mathrm{i}}$ is a key parameter for the weak acid hypothesis, few investigations have measured the $\mathrm{pH}^{\mathrm{i}}$ along with the absorption studies.

In the present study, in order to overcome these difficulties, the absorption of 2,4-D by corn root protoplasts was investigated considering not only the extracellular $\mathrm{pH}\left(\mathrm{pH}^{\circ}\right)$ but also the $\mathrm{pH}^{\mathrm{i}}$. The $\mathrm{pH}^{\mathrm{i}}$ of the protoplasts was measured by the 5,5-dimethyloxazolidine2,4-dione (DMO) distribution technique. ${ }^{8-10)}$ The protoplasts were used to eliminate the uncertainties associated with the cell wall or Donnan phase. ${ }^{11)}$ Corn roots were selected as the source of protoplasts since experimental evidence had suggested that enzymatically isolated protoplasts from corn roots retain the normal transport properties. ${ }^{12-14)}$ Using this system, we quantitatively evaluated the validity of the weak acid hypothesis as the mechanism for the absorption of 2,4-D.

\section{MATERIALS AND METHODS}

\section{Plant Material}

Corn (Zea mays L. cv Pioneer 3377) seeds were surface-sterilized in $1 \% \mathrm{NaOCl}$ for $10 \mathrm{~min}$ and rinsed with deionized water. The seeds were allowed to germinate on germination paper saturated with $0.5 \mathrm{~mm} \mathrm{CaSO}_{4}$ at $27 \pm 1^{\circ} \mathrm{C}$ in the dark. The seedlings were collected for protoplast isolation after $60 \mathrm{hr}$ of germination, at which time the primary roots of the seedlings were typically 5 to $8 \mathrm{~cm}$ long.

\section{Protoplast Isolation}

Protoplasts were isolated by the procedures described previously, ${ }^{12-14)}$ with modifications. Chopped cortical segments from the primary roots were digested with a medium containing $0.6 \mathrm{~m}$ mannitol, $1 \mathrm{mM} \mathrm{CaCl}_{2}, 2 \%$ (w/v) Cellu- lysin (Calbiochem), $\quad 0.1 \% \quad(\mathrm{w} / \mathrm{v})$ Pectinase (Cooper Biomedical), $0.05 \% \quad(\mathrm{w} / \mathrm{v})$ BSA (Sigma, fraction $\mathrm{V}$ ) and $0.5 \mathrm{~mm}$ dithiothreitol (pH 5.6) for $4 \mathrm{hr}$ in the dark at $27 \pm 1^{\circ} \mathrm{C}$ with circular shaking $(50 \mathrm{rpm})$. The mixture was filtrated through an $80-\mu \mathrm{m}$ nylon filter and the filtrate was centrifuged $(180 \times g, 6 \mathrm{~min})$. The pellet was resuspended in a suspension medium (0.63 m mannitol, $0.1 \mathrm{~mm} \mathrm{CaCl}_{2}, \quad 0.5 \mathrm{~mm}$ dithiothreitol, $2.5 \mathrm{~mm}$ Tris-MES, $\mathrm{pH}$ 6.5) and centrifuged again. The pellet was suspended in $12 \%(\mathrm{w} / \mathrm{v})$ Ficoll solution containing $0.63 \mathrm{M}$ mannitol, $0.1 \mathrm{mM} \mathrm{CaCl}_{2}$ and $1.25 \mathrm{~mm}$ Tris-MES $(\mathrm{pH} 6.5)$, and overlaid with similar solutions of 8,5 and $0 \%(\mathrm{w} / \mathrm{v})$ Ficoll. The gradient was centrifuged $(360 \times g, 12 \mathrm{~min})$ and the protoplasts were collected between the 0 and $5 \%$ Ficoll layers. The protoplasts were diluted in a suspension medium and centrifuged (180 $\times g, 6 \mathrm{~min})$. The final pellet was used for subsequent experiments by suspending it into an absorption medium $(0.63 \mathrm{M}$ mannitol, 0.1 $\mathrm{mm} \mathrm{CaCl}, 0.1 \mathrm{~mm} \mathrm{KCl}, 10 \mathrm{~mm}$ Tris-MES, desired $\mathrm{pH}$ from 4.5 to 7.5 depending on the $\mathrm{pH}^{\circ}$ condition). For experiments at $\mathrm{pH}^{\circ}<$ 4.5 , the absorption medium contained $10 \mathrm{~mm}$ citrate- $\mathrm{KOH}$ instead of Tris-MES. The protoplast number was determined with a hemacytometer and the protein content of protoplasts was determined by a modified Lowry method. ${ }^{15)}$

\section{Protoplast Volume Determination}

The protoplast volume was determined by the method described previously, ${ }^{16)}$ with modifications. The protoplast suspension (500 to $2000 \times 10^{3}$ protoplasts) was added to the absorption medium ( $\mathrm{pH}$ 6.5) containing 3.11 $\mu \mathrm{Ci}{ }^{3} \mathrm{H}_{2} \mathrm{O}$ (ICN Radiochemicals, $100 \mathrm{mCi} / \mathrm{ml}$ ) and $0.83 \mu \mathrm{Ci}{ }^{14} \mathrm{C}$-mannitol (ICN Radiochemicals, uniformly labeled, $42 \mathrm{mCi} / \mathrm{mmol}$ ) to give a final volume of $2.3 \mathrm{ml}$ in a $10-\mathrm{ml}$ Erlenmeyer flask. After 20 min incubation in the dark at $27 \pm 1{ }^{\circ} \mathrm{C}$ with circular shaking (50 rpm), 200 $\mu \mathrm{l}$ of the mixture was placed on top of a $70-\mu \mathrm{l}$ layer of $1.0421 \mathrm{~g} / \mathrm{ml}$ silicone oil which was layered on top of $50 \mu \mathrm{l}$ of an osmoticum layer $\left(0.78 \mathrm{~m}\right.$ mannitol, $0.1 \mathrm{~mm} \mathrm{CaCl}_{2}, 0.1 \mathrm{~mm} \mathrm{KCl}$, $1 \mathrm{~mm}$ Tris-MES, $\mathrm{pH} 6.5$ ) in a $400-\mu 1$ microfuge tube. The microfuge tube was centrifuged with a Beckman Microfuge $11(6800 \times g, 30$ 
sec) to separate protoplasts from the radioactive medium by pelleting them through the silicone oil layer. Immediately after the centrifugation, the microfuge tube was frozen in dry ice-acetone. The tip of the tube was cut off at the silicone oil layer and placed in $10 \mathrm{ml}$ of scintillation fluid $(0.26 \mathrm{~g}$ POPOP, $13.16 \mathrm{~g}$ PPO, $131.6 \mathrm{~g}$ naphthalene, $632 \mathrm{ml}$ absolute ethanol, $1000 \mathrm{ml} \mathrm{1,4-dioxane,} 1000 \mathrm{ml}$ toluene), and the radioactivity was determined with a liquid scintillation spectrometer (Beckman, LS-9800).

The protoplast volume and the occuluded volume were determined assuming that ${ }^{3} \mathrm{H}_{2} \mathrm{O}$ can freely diffuse through membranes of the protoplasts while ${ }^{14} \mathrm{C}$-mannitol cannot.

\section{Procedure for 2,4-D Absorption}

The absorption of 2,4-D was initiated by adding the suspension containing 1200 to $1300 \times 10^{3}$ protoplasts to the absorption medium containing $0.22 \mu \mathrm{Ci}$ of 2,4-dichlorophenoxy[2- $\left.{ }^{14} \mathrm{C}\right]$ acetic acid $\left({ }^{14} \mathrm{C}-2,4-\mathrm{D}\right.$, Amersham, $55 \mathrm{mCi} / \mathrm{mmol}$ ) to give a final volume of $2.3 \mathrm{ml}$ in a $10-\mathrm{ml}$ Erlenmeyer flask. The concentration of 2,4-D in the absorption medium was adjusted to $2 \mu \mathrm{M}$ by adding nonradioactive $2,4-\mathrm{D}$ prior to the addition of the protoplast suspension. The absorption mixture was incubated in the dark at $27 \pm 1^{\circ} \mathrm{C}$ with circular shaking $(50 \mathrm{rpm})$. Periodically, an aliquot $(200 \mu \mathrm{l})$ of the incubation mixture was sampled and the ${ }^{14} \mathrm{C}$ radioactivity absorbed by the protoplasts was determined by the same microfuge-separation technique described in the volume determination procedure.

\section{Determination of $p H^{1}$}

The $\mathrm{pH}^{\mathrm{i}}$ of corn root protoplasts was determined by the DMO distribution technique. $^{8-10)}$ The suspension containing 500 to $600 \times 10^{3}$ protoplasts was added to the absorption medium to give a final volume of $1 \mathrm{ml}$ in a 10-ml Erlenmeyer flask. The suspension mixture was incubated in the dark at $27 \pm 1{ }^{\circ} \mathrm{C}$ with circular shaking (50 rpm). After incubating for $30 \mathrm{~min}, 0.15 \mu \mathrm{Ci}$ of 5,5-dimethyloxazolidine-2 $\left[{ }^{14} \mathrm{C}\right], 4$-dione $\quad\left({ }^{14} \mathrm{C}-\mathrm{DMO}, \quad\right.$ New England Nuclear, $43.2 \mathrm{mCi} / \mathrm{mmol}$ ) in $10 \mu \mathrm{l}$ of absolute ethanol was added to the suspension and the incubation was continued for another
$15 \mathrm{~min}$. The net accumulation of DMO by the protoplasts was determined by the same microfuge-separation technique described in the volume determination procedure. The $\mathrm{pH}^{1}$ was calculated from the following equation: $:^{8-10)}$

$$
\begin{aligned}
\mathrm{pH}^{\mathrm{i}}= & 6.30 \\
& +\log \left[\frac{[\mathrm{DMO}]^{\mathrm{i}}}{[\mathrm{DMO}]^{\mathrm{o}}}\left\{1+10^{\left(\mathrm{pH}^{\mathrm{o}-6.30)}\right.}\right\}-1\right]
\end{aligned}
$$

where $[\mathrm{DMO}]^{1}$ and $[\mathrm{DMO}]^{\circ}$ are the DMO concentrations inside and outside the protoplasts, respectively.

\section{RESULTS}

\section{Protoplast Characterization}

The protoplast yields were 300 to $700 \times 10^{3}$ protoplasts/g fresh weight cortical tissue, resembling those reported previously. ${ }^{12-14)}$ The isolated protoplasts accumulated neutral red dye in the vacuole and fluorescein diacetate dye in the cytoplasm, indicating their intactness (Fig. 1). The intactness of the protoplasts shown in Fig. 1 was essential for 2,4-D absorption studies as will be described later. Approximately $10^{6}$ protoplasts contained $c a$. $800 \mu \mathrm{g}$ protein. The protoplast volume and the occluded volume were linearly correlated to the protein content, and were $6.86 \mu \mathrm{l}$ and $0.78 \mu \mathrm{l} / 100 \mu \mathrm{g}$ protein, respectively (Fig. 2). These values were used for exact calculation of intracellular solute concentration. From these values, the average diameter of the protoplasts is calculated to be $47.16 \mu \mathrm{m}$, which is in good agreement with the microscopic observation (Fig. 1A).

\section{Absorption of 2,4-D by Protoplasts}

The absorption of 2,4-D by the protoplasts was measured under wide $\mathrm{pH}$ variations. The $\mathrm{pH}^{\circ}$ markedly affected 2,4-D absorption (Figs. 3 and 4). The absorption increased as the $\mathrm{pH}^{\circ}$ decreased. The ratio of the 2,4-D concentration inside to outside the protoplasts $\left(c^{\mathrm{i}} / c^{\circ}\right)$ reached $c a .1 .2,4.0,10-12$ and $30-40$ at $\mathrm{pH}^{\circ} 7.5,6.5,5.5$ and 4.5 respectively within 75 min incubation (Fig. 3). At $\mathrm{pH}^{\circ} 3.5$ and 2.8 , the $c^{i} / c^{\circ}$ ratio reached $c a .90$ and 150 respectively within $15 \mathrm{~min}$, but the once absorbed 2,4-D was rapidly released from the 

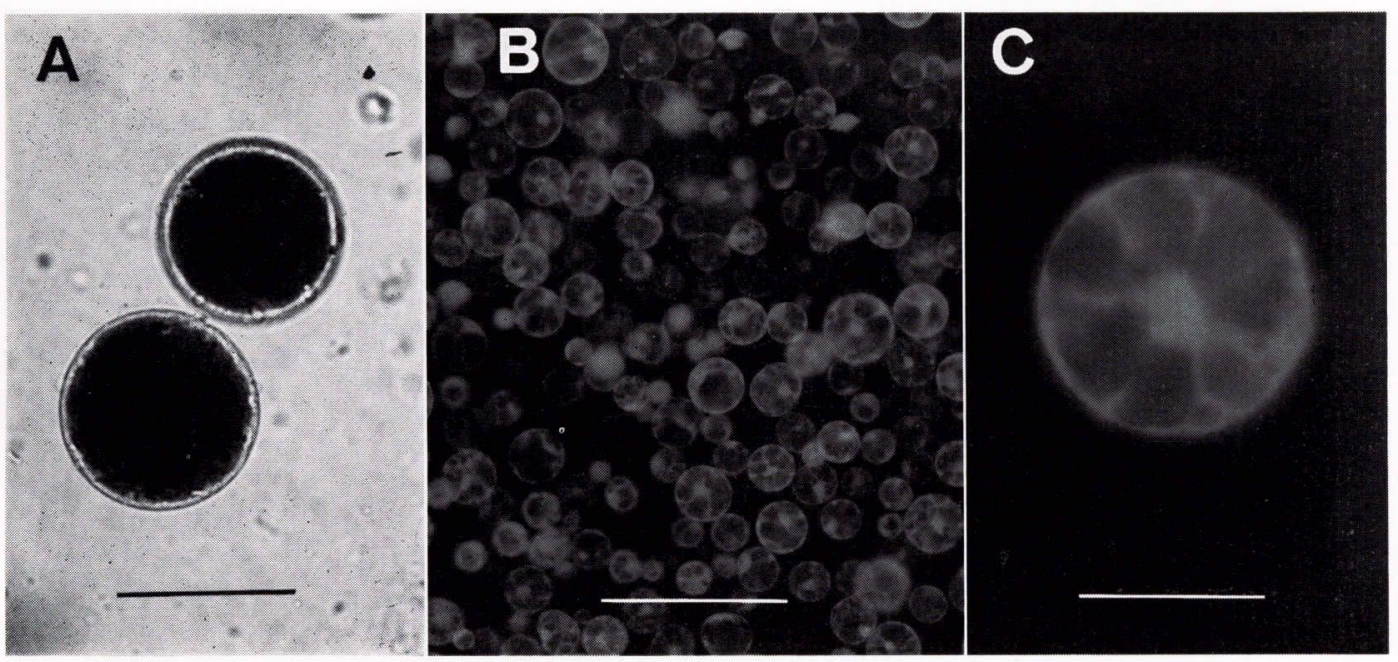

Fig. 1 Light micrographs of corn root protoplasts.

(A) Bright field observation with the treatment of neutral red dye. Bar represents $50 \mu \mathrm{m}$. The diameters of typical protoplasts are approximately $50 \mu \mathrm{m}$, and neutral red dye is accumulated in the large central vacuole. (B) Reflected fluorescence observation with the treatment of fluorescein diacetate. Bar represents $200 \mu \mathrm{m}$. Most of the population of the protoplasts accumulate fluorescein, indicating their intactness. (C) Same as (B) except for magnification. Bar represents $50 \mu \mathrm{m}$. The thin layer of cytoplasm accumulates fluorescein higher than large central vacuole, and transvacuolar strands and nucleus (a bright spot at the center of the protoplast) can be seen.

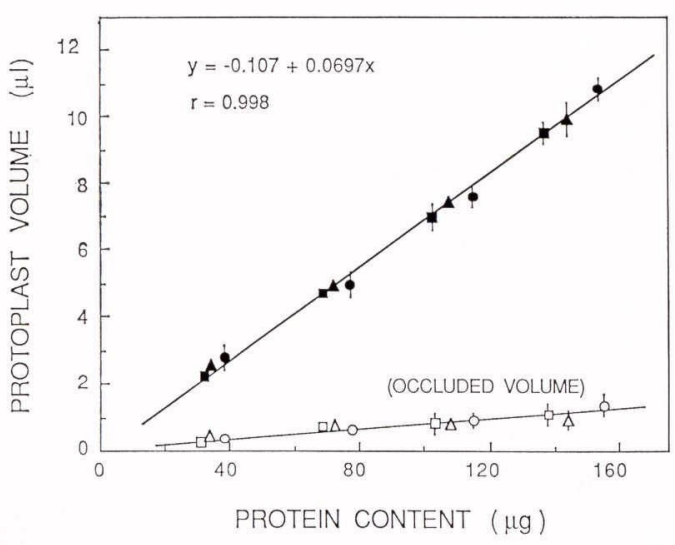

Fig. 2 Relationship between protein content and protoplast volume.

Closed and open symbols represent protoplast volume and occluded volume, respectively. Different shapes of symbols represent different isolation dates. In this and the subsequent figures, data points and error bars represent the mean $\pm \mathrm{SD}$, and points without error bars had the SD smaller than symbols used.

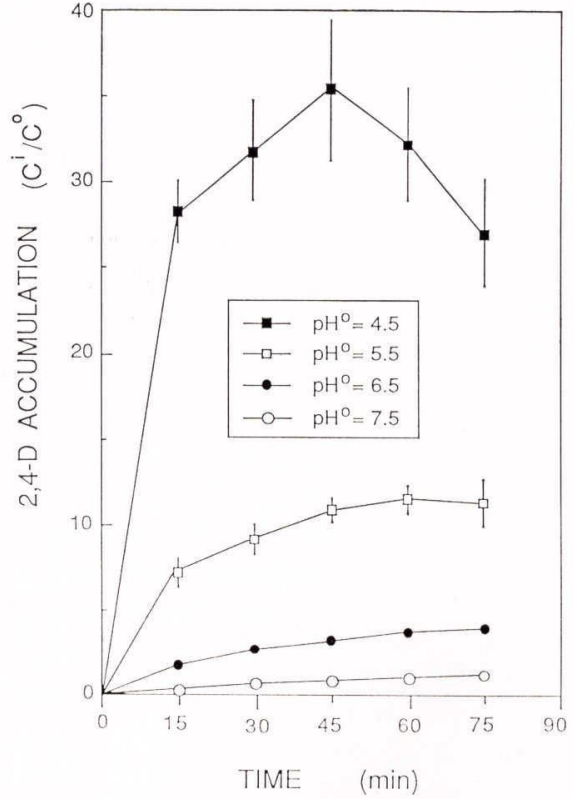

Fig. 3 Effect of $\mathrm{pH}^{\circ}$ (7.5 to 4.5 ) on 2,4-D accumulation by corn root protoplasts. 


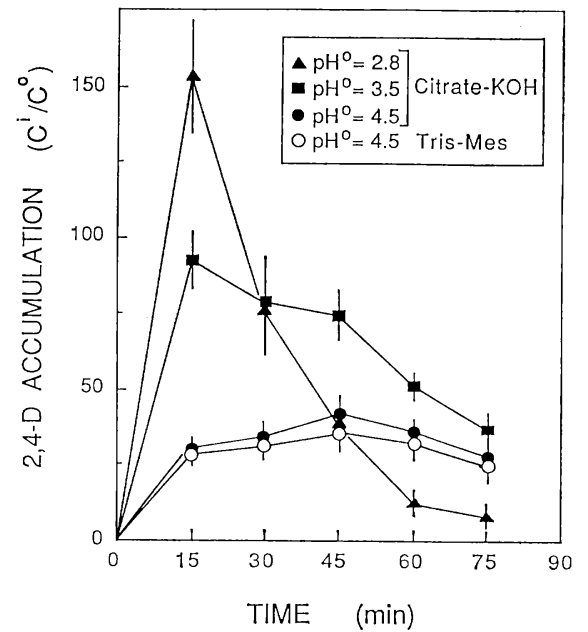

Fig. 4 Effect of low $\mathrm{pH}^{\mathrm{o}}$ (4.5 to 2.8) on 2,4-D accumulation by corn root protoplasts.

protoplasts after 15-min incubation (Fig. 4). The microscopic observation using fluorescein diacetate dye indicated that the release of the once absorbed 2,4-D shown in Fig. 4 was a function of the death of the protoplasts, suggesting that the 2,4-D absorption process is not a purely physical process but at least requires cell intactness.

\section{3. $p H^{\mathrm{i}}$ of Protoplasts}

The $\mathrm{pH}^{\mathrm{i}}$ of the protoplasts was stable at approximately 6.7 to 6.8 during the $60-\mathrm{min}$ incubation at $\mathrm{pH}^{\circ} 6.5$, and the treatment with $2 \mu \mathrm{m} 2,4-\mathrm{D}$ did not affect the $\mathrm{pH}^{\mathrm{i}}$ throughout the incubation time (Fig. 5). The change of the $\mathrm{pH}^{1}$ as influenced by the $\mathrm{pH}^{\circ}$ variation (7.5 to 4.5 ) was relatively small (6.9 to 6.6$)$, indicating that the cells are able to maintain their $\mathrm{pH}^{\mathrm{i}}$ within a small range even under wide $\mathrm{pH}^{\circ}$ variations (Fig. 6). The presence of $2 \mu \mathrm{M} 2,4-\mathrm{D}$ did not affect the $\mathrm{pH}^{\mathrm{i}}$ and $\mathrm{pH}^{\circ}$ relationship as shown in Fig. 6.

The $\mathrm{pH}^{\mathrm{i}}$ determined by the DMO distribution technique is for "overall intracellular $\mathrm{pH}^{\text {" }}$ since the technique has no spatial resolution of subcellular compartments. ${ }^{8-10}$ ) However, although one cannot determine cytoplasmic $\mathrm{pH}\left(\mathrm{pH}^{\text {cyt }}\right)$ and vacuolar $\mathrm{pH}\left(\mathrm{pH}^{\text {vac }}\right)$ from the $\mathrm{pH}^{\mathrm{i}}$, one can estimate the $\mathrm{pH}^{\mathrm{cyt}}$ and $\mathrm{pH}^{\mathrm{vac}}$ which give the observed $\mathrm{pH}^{\mathrm{i}}$ from the following relationship. ${ }^{8,9)}$

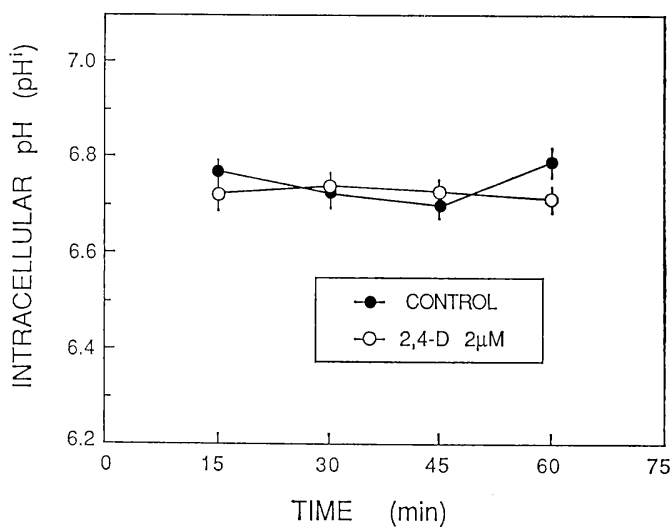

Fig. 5 The $\mathrm{pH}^{\mathrm{i}}$ of corn root protoplasts during incubation time at $\mathrm{pH}^{\circ} 6.5$ with and without 2,4D treatment.

The incubation conditions were identical to that for the 2,4-D absorption studies. For the 2,4-D treatment, $2 \mu \mathrm{M}$ of the non-radiolabeled 2,4-D was added prior to the incubation.

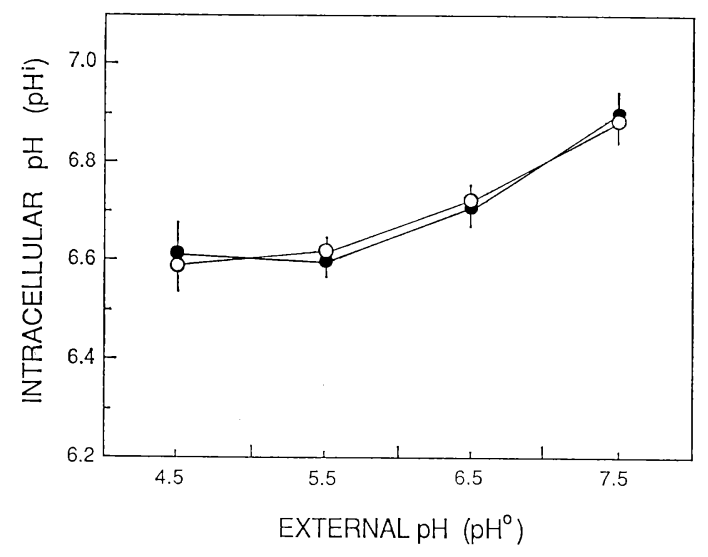

Fig. 6 Effect of $\mathrm{pH}^{\circ}$ on the $\mathrm{pH}^{\mathrm{i}}$ of corn root protoplasts.

Closed and open symbols represent the data measured in the absence and the presence, respectively, of $2 \mu \mathrm{M}$ of nonradioactive 2,4-D. The incubation conditions were identical to that for the 2,4-D absorption studies.

$$
\begin{gathered}
10^{\mathrm{pH}^{\mathrm{i}}=} V^{\mathrm{cyt}} 10^{\mathrm{pH}^{\mathrm{cyt}}}+V^{\mathrm{vac}} 10^{\mathrm{pH}^{\mathrm{vac}}} \\
\left(V^{\mathrm{cyt}}+V^{\mathrm{vac}}=1\right)
\end{gathered}
$$

where $V^{\text {cyt }}$ and $V^{\mathrm{vac}}$ are the relative volumes of cytoplasm and vacuole respectively. It is important to note that Eq. (2) is not a general principle but a valid equation when $\mathrm{pH}^{1}$ is 
of the values presents two important indications.

First, in terms of a qualitative comparison, the observed effect of $\mathrm{pH}^{\circ}$ on 2,4-D accumulation is similar to the theoretically expected accumulation from the weak acid hypothesis, where a lower $\mathrm{pH}^{\circ}$ gives a higher $c^{\mathrm{i}} / c^{\circ}$. When the $P_{\mathrm{m}} / P_{\mathrm{a}}$ ratio is to be $1 \times 10^{5}$ or larger, some of the theoretical values are similar to the observed ones at $\mathrm{pH}^{\circ} 4.5$ and 5.5. This suggests that the mechanism of the weak acid hypothesis may be partly involved in 2,4-D absorption, provided that the $P_{\mathrm{m}} / P_{\mathrm{a}}$ ratio of $2,4-\mathrm{D}$ is at least $1 \times 10^{5}$.

Second, in terms of a strictly quantitative comparison, the theoretically expected values did not completely agree with the observed data. In Table 1 , the $c^{\mathrm{i}} / c^{\mathrm{o}}$ ratio theoretically becomes maximal when $P_{\mathrm{m}} / P_{\mathrm{a}}$ is assumed to be infinite $(\infty)$ at either $\mathrm{pH}^{\circ}$ condition. Thus, the 2,4-D accumulation $\left(c^{\mathrm{i}} / c^{\circ}\right)$ cannot exceed 1.62 and 0.25 at $\mathrm{pH}^{\circ} 6.5$ and 7.5 respectively, as long as only the weak acid hypothesis operates 2,4-D absorption. The observed 2,4$\mathrm{D}$ accumulations at $\mathrm{pH}^{\circ} 6.5$ and 7.5 , however, were 4.0 and 1.2 respectively, which are significantly greater than their respective theoretical maxima. It is clear that the weak acid hypothesis alone does not explain the observed absorption of 2,4-D by protoplasts, and some additional mechanism(s) must be involved at least at $\mathrm{pH}^{\circ} 6.5$ and 7.5. This mechanism should be an active transport process because the observed absorption of 2,4-D exceeded the passive diffusion equilibrium expected from the weak acid hypothesis. The active component might be a carriermediated transport by the proposed auxin carrier. ${ }^{22)}$ In the following paper, we will report on further study on the active component.

In conclusion, the present results suggested that the mechanism of the weak acid hypothesis may be partly involved but it alone cannot explain 2,4-D absorption by protoplasts and that an active process must be involved at least at $\mathrm{pH}^{\circ} 6.5$ and 7.5.

\section{ACKNOWLEDGMENTS}

We wish to thank Drs. Floyd M. Ashton and Bruce A. Bonner, University of California, Davis, for their helpful suggestions and discussions.

\section{REFERENCES}

1) F. M. Ashton \& A. S. Crafts: "Mode of Action of Herbicides," 2nd Ed., John Willey and Sons, New York, p. 276, 1981

2) D. E. Bayer \& J. M. Lumb: "Pesticide Formulations," ed. by W. Valkenburg, Marcel Dekker, New York, pp. 387-439, 1973

3) L. V. Edgington: Ann. Rev. Phytopathol. 19 107 (1981)

4) G. G. Briggs, R. L. O. Rigitano \& R. H. Bromilow: Pestic. Sci. 19, 101 (1987)

5) C. A. Peterson \& L. V. Edgington: Pestic. Sci. 7, 483 (1976)

6) C. E. Crisp \& M. Look: "Advances in Pesticide Science," ed. by H. Geissbühler, Vol. 3, Pergamon, New York, pp. 430-437, 1979

7) J. A. Raven: New Phytol. 74, 163 (1975)

8) A. Kurkdjian \& J. Guern: Plant Sci. Lett. 11, 337 (1978)

9) J. J. Leguay: Biochim. Biophys. Acta 497, 329 (1977)

10) N. A. Walker \& F. A. Smith: Plant Sci. Lett. 4, 125 (1975)

11) P. S. Nobel: "Biophysical Plant Physiology and Ecology," W. H. Freeman and Company, San Francisco, p. 134, 1983

12) J. W. Gronwald \& R. T. Leonard: Plant Physiol. 70, 1391 (1982)

13) L. V. Kochian \& W. J. Lucas: Plant Physiol. 73, 208 (1983)

14) J. Lynch, G. R. Cramer \& A. Läuchli: Plant Physiol. 83, 390 (1987)

15) G. L. Peterson: Anal. Biochem. 83, 346 (1977)

16) G. L. Darmstadt, N. E. Balke \& L. E. Schrader: Pestic. Biochem. Physiol. 19, 172 (1983)

17) J. K. M. Roberts, P. M. Ray, N. WadeJardetzky \& O. Jardetzky: Nature 283, 870 (1980)

18) J. A. Raven: Sci. Prog. Oxf. 69, 495 (1985)

19) F. A. Smith \& J. A. Raven: Ann. Rev. Plant Physiol. 30, 289 (1979)

20) R. T. Wedding \& L. C. Erickson: Plant Physiol. 32, 503 (1957)

21) P.S. Nobel: "Biophysical Plant Physiology and Ecology," W. H. Freeman and Company, San Francisco, p. 533, 1983

22) M. H. M. Goldsmith: Ann. Rev. Plant Physiol. 27, 439 (1977) 


\section{要 約}

\section{トウモロコシ根プロトプラストの 2,4-D 吸収機} 構における弱酸仮説の定量的評価*

河西史人, David E. Bayer

トゥモロコシ根皮層より酵素的に単離されたプロトプ ラストの 2, 4-D 吸収を細胞内外の $\mathrm{pH}$ と関連して検討 した. 2, 4-D 吸収は細胞外 $\mathrm{pH}\left(\mathrm{pH}^{\circ}\right)$ の低下とともに増 大した．プロトプラスト外部に対する内部の $2,4-\mathrm{D}$ 濃 度比 $\left(c^{1} / c^{0}\right)$ は $\mathrm{pH}^{\circ} 7.5,6.5,5.5,4.5$ において 75 分 以内の培養でおのおの約 $1.2 ， 4.0 ， 10 \sim 12 ， 30 \sim 40$ に 達した. $\mathrm{pH}^{\mathrm{o}} 3.5,2.8$ においては 15 分以内に $c^{\mathrm{i}} / c^{0}$ 比が

*トウモロコシ根プロトプラストの 2,4-D 吸収に及ぼ す細胞内 $\mathrm{pH}$ の影響（第 1 報）
おのおの約 $90 ， 150$ に達したが，吸収された 2,4-D は その後プロトプラストの死により速やかに放出された.

5，5-ジメチルオキサゾリジン-2，4-ジオン分配法によ る細胞内 $\mathrm{pH}\left(\mathrm{pH}^{\mathrm{i}}\right)$ 測定の結果, $\mathrm{pH}^{\circ}$ 変化 $(7.5 \sim 4.5)$ による $\mathrm{pH}^{1}$ 変化は比較的小さかった $(6.9 \sim 6.6)$. これら の $\mathrm{pH}^{\mathrm{i}}$ 測定值を用いて各 $\mathrm{pH}^{\circ}$ におケる理論的 $c^{\mathrm{i}} / c^{\circ}$ 比 を弱酸仮説に基づいて推定した． $\mathrm{pH}^{\circ}$ 変化に対する理論 值の傾向は大まかには実測值の傾向を反映したが， $\mathrm{pH}^{\circ}$ 6.5 および 7.5 における $c^{\mathrm{i}} / c^{\mathrm{o}}$ 比実測值はおのおのの理 論的最大值を顕著に上回っていた。これらの結果は，プ ロトプラストによる $2,4-\mathrm{D}$ 吸収が単に弱酸仮説のみで は説明されえず，少なくとも $\mathrm{pH}^{\circ} 6.5$ および 7.5 におい ては能動的な輸送の関与していることを示唆する. 